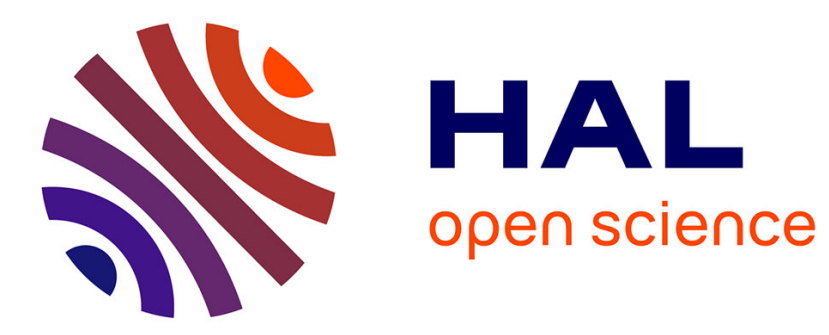

\title{
Accumulators for the Capture of Heavy Metals in Thermal Conversion Systems
}

Pierre-Marie Nigay, Ange Nzihou, Claire E White, Winston Soboyejo

\section{To cite this version:}

Pierre-Marie Nigay, Ange Nzihou, Claire E White, Winston Soboyejo. Accumulators for the Capture of Heavy Metals in Thermal Conversion Systems. Journal of Environmental Engineering, 2018, 144 (12), pp.art. no. 04018118. 10.1061/(ASCE)EE.1943-7870.0001469 . hal-01894538

\section{HAL Id: hal-01894538 https://imt-mines-albi.hal.science/hal-01894538}

Submitted on 12 Nov 2019

HAL is a multi-disciplinary open access archive for the deposit and dissemination of scientific research documents, whether they are published or not. The documents may come from teaching and research institutions in France or abroad, or from public or private research centers.
L'archive ouverte pluridisciplinaire HAL, est destinée au dépôt et à la diffusion de documents scientifiques de niveau recherche, publiés ou non, émanant des établissements d'enseignement et de recherche français ou étrangers, des laboratoires publics ou privés. 


\title{
Accumulators for the Capture of Heavy Metals in Thermal Conversion Systems
}

\author{
Pierre-Marie Nigay ${ }^{1}$; Ange Nzihou ${ }^{2}$; Claire E. White ${ }^{3}$; and Winston O. Soboyejo ${ }^{4}$
}

\begin{abstract}
A clay ceramic with organic additives (biomass and biochar) was investigated for the development of highly porous accumulators to capture heavy metals in thermal conversion systems. The structure was characterized using X-ray pair distribution function analysis, differential scanning calorimetry, and scanning electron microscopy. It was found that the organic additives transformed into porosity during firing. The morphology of the pores also corresponded to the morphology of the organic additives. Hence, the clay ceramic with a 15 -wt $\%$ addition of biochar had a porosity of $46 \mathrm{vol} \%$ with $20-\mu \mathrm{m}$ interconnected pores after firing. The resulting accumulator was found to capture cadmium (a model for heavy metals with high volatility) via condensation of the cadmium vapor as $2-\mu \mathrm{m}$ beads in the pores. The cadmium capture efficiency reached up to $57 \%$ using a 15 -wt $\%$ addition of biochar. Furthermore, cadmium was captured at higher temperatures than the condensation temperature in the atmosphere. This means that heavy metals may be captured before they condense in fly ash to promote the recycling of this material.
\end{abstract}

Author keywords: Clay ceramic; Organic additives; Porosity; Heavy metals; Thermal conversion systems.

\section{Introduction}

Thermal conversion is an efficient way to recover energy from municipal solid waste (MSW) and biomass. Energy stored in MSW and biomass can be converted into heat and electricity by the application of thermal conversion processes such as combustion (McKendry 2002). Moreover, thermal conversion processes such as gasification can convert energy stored in MSW and biomass into fuel for transportation (Bridgwater 2003). Hence, energy harvested from MSW and biomass conversion is an alternative route to the current approach using fossil fuels, and therefore contributes toward the objectives of reducing the impact of energy consumption on the global environment (Garg et al. 2007; Steubing et al. 2012). Nevertheless, the thermal conversion of MSW and biomass also generates some potentially toxic emissions.

The potential toxicity of thermal conversion emissions depends on the MSW and biomass composition (Wiedinmyer et al. 2014). In fact, some conventional elements of MSW and biomass become toxic when subjected to the thermal conversion temperatures of $800-1,000^{\circ} \mathrm{C}$ (Luo and Zhou 2012). Chlorine from MSW contributes to the formation of human carcinogenic substances such as dioxins (Lavric et al. 2004). Sulfur and nitrogen elements from

\footnotetext{
${ }^{1}$ Postdoctoral Researcher, Centre RAPSODEE, Ecole des Mines d'Albi, Campus Jarlard, Route de Teillet, 81013 Albi Cedex 09, France (corresponding author). Email: pierre-marie.nigay@mines-albi.fr

${ }^{2}$ Professor, Centre RAPSODEE, Ecole des Mines d'Albi, Campus Jarlard, Route de Teillet, 81013 Albi Cedex 09, France. Email: ange .nzihou@mines-albi.fr

${ }^{3}$ Assistant Professor, Dept. of Civil and Environmental Engineering, Andlinger Center for Energy and the Environment, Princeton Univ., Princeton, NJ 08544. Email: whitece@princeton.edu

${ }^{4}$ Dean of Engineering, Professor, Dept. of Mechanical Engineering, Worcester Polytechnic Institute, Worcester, MA 01609. Email: wsoboyejo@wpi.edu
}

biomass also transform into greenhouse gases [sulfur oxides (SOx), nitrogen oxides (NOx)] that are partly responsible for climate change (Williams et al. 2012). Nevertheless, such emissions are well controlled using traditional air pollution control devices (scrubbers) (Vehlow 2015).

The most concerning issue related to the emissions from thermal conversion systems is the release of heavy metals. Exposure to heavy metals may lead to reduced intellectual ability, kidney disorder, or bone damage (Kampa and Castanas 2008). Hence, environmental and legal standards require drastic control of heavy metal emissions in thermal conversion systems (Pacyna et al. 2007). The control of heavy metal emissions depends on the volatility of heavy metals. Heavy metals with low volatilities such as iron $(\mathrm{Fe})$ and copper $(\mathrm{Cu})$ remain in the inorganic fraction of MSW and biomass that is collected at the bottom of the furnace (>70 wt\% of heavy metals with low volatilities remain in the bottom ash) (Narodoslawsky and Obernberger 1996).

However, heavy metals with high volatilities such as mercury $(\mathrm{Hg})$ and cadmium $(\mathrm{Cd})$ are vaporized in the thermal conversion system ( $>90 \mathrm{wt} \%$ of heavy metals with high volatilities are vaporized) (Dong et al. 2015). The vaporization of such heavy metals is promoted by the chemical heterogeneity of MSW and biomass. For instance, the presence of chlorine reduces the vaporization temperature of cadmium from $1,559^{\circ} \mathrm{C}$ in the form of oxide $(\mathrm{CdO})$ to $568^{\circ} \mathrm{C}$ in the form of chloride $\left(\mathrm{CdCl}_{2}\right)$ (Abanades et al. 2002). This vapor released in the thermal conversion system is subjected to condensation in the cooler sections. However, most of the vapor condenses in the inorganic fraction of MSW and biomass that is entrained in the flue gas (fly ash) (Levasseur et al. 2006).

Since most of the highly volatile heavy metals end up in the fly ash, the capture of such heavy metals is largely completed by the fly ash collection processes. The collection of fly ash is relatively well controlled in thermal conversion systems using electrostatic precipitators or bag-house filters (Yang and Beltran 2000). However, the contamination of fly ash limits the extent to which this material can be recycled in road and concrete applications (Ferreira et al. 2003). The conservation of highly volatile heavy metals in the bottom ash can prevent the contamination of fly ash. It may be achieved by injecting solid sorbents such as clays, aluminum oxides, or 
limestone in the furnaces (Chen et al. 2001). Nevertheless, the utilization of inorganic sorbents also results in an extensive increase of the total weight (and volume) of thermal conversion residues.

Porous ceramics are of interest for the capture of highly volatile heavy metals. Such heavy metals can be captured by circulation of the vapor through the porous material (Kemiha et al. 2014). Because of their thermal stability, up to $1,000^{\circ} \mathrm{C}$ (Carty and Senapati 1998), the porous ceramics can be inserted directly after the furnace to capture heavy metals before they condense in fly ash. The heavy metals can also be removed afterward by dissolution, using a fluid circulating system. This means that the porous ceramics can be reused to prevent an increase in the total amount of thermal conversion residues. But, a high percentage of porosity with interconnected pores remains essential for such a capture process. Therefore, the objective of this study was to investigate the structure of a clay ceramic with organic additives for the development of highly porous accumulators to capture highly volatile heavy metals in thermal conversion systems.

\section{Materials and Methods}

\section{Raw Materials}

The clay that was used in this study was extracted in the form of lumps from a clay quarry (France). The lumps of clay were ground into smaller lumps of approximately $3 \mathrm{~mm}$ using a rolling mill (LA 1527, Vicentini, Vicenza, Italy). This operation was done to promote the dispersion of the additives and increase the homogeneity (composition, water content) of the mixtures. The elemental composition of the clay was measured using X-ray fluorescence analysis (Epsilon 3-XL, PANalytical, Almelo, Netherlands). The clay was composed of silicon (57.1 wt $\%$ ) and aluminum (14.5 wt \%) oxides, with smaller concentrations of calcium (8.9 wt $\%$ ), iron $(6.2 \mathrm{wt} \%)$, potassium (3.0 wt $\%)$, and magnesium (2.2 $\mathrm{wt} \%$ ) oxides.

The organic additives that were used in this study consisted of biomass and biochar. The biomass was produced by grinding wood (red alder) with a knife mill (Pulverisette 15, Fritsch, IdarOberstein, Germany). On the other hand, the biochar was produced by the pyrolysis of the biomass. The pyrolysis was conducted at a low temperature of $500^{\circ} \mathrm{C}$ to maximize the production of biochar. At $500^{\circ} \mathrm{C}$, the solid fraction (i.e., biochar) accounts for $10-25 \mathrm{wt} \%$ in the products of the pyrolysis, while the gas fraction (synthetic gas) accounts for 15-30 wt $\%$, and the liquid fraction (bio-oil) for approximately $50 \mathrm{wt} \%$ (Bridgwater 2012).

The elemental composition of the organic additives, measured via CHONS (carbon, hydrogen, oxygen, nitrogen, sulfur) analysis (Flash 2000, Thermo Fisher Scientific, Waltham, Massachusetts), is given in Table 1. The results show that the organic additives are composed of carbon, hydrogen, and oxygen. The concentration of oxygen in the biochar is relatively low compared with that in the biomass.

The particle size distribution of the organic additives was measured via laser granulometry analysis (Mastersizer 3000, Malvern

Table 1. Elemental composition of the organic additives with the concentrations in carbon, hydrogen, oxygen, nitrogen, and sulfur elements

\begin{tabular}{lccccc}
\hline & \multicolumn{5}{c}{ Concentration (wt\%) } \\
\cline { 2 - 6 } Sample & $\mathrm{C}$ & $\mathrm{H}$ & $\mathrm{O}$ & $\mathrm{N}$ & $\mathrm{S}$ \\
\hline Biomass & 49.5 & 6.8 & 42.4 & 0.2 & 0.0 \\
Biochar & 84.9 & 4.0 & 9.8 & 0.5 & 0.0 \\
\hline
\end{tabular}

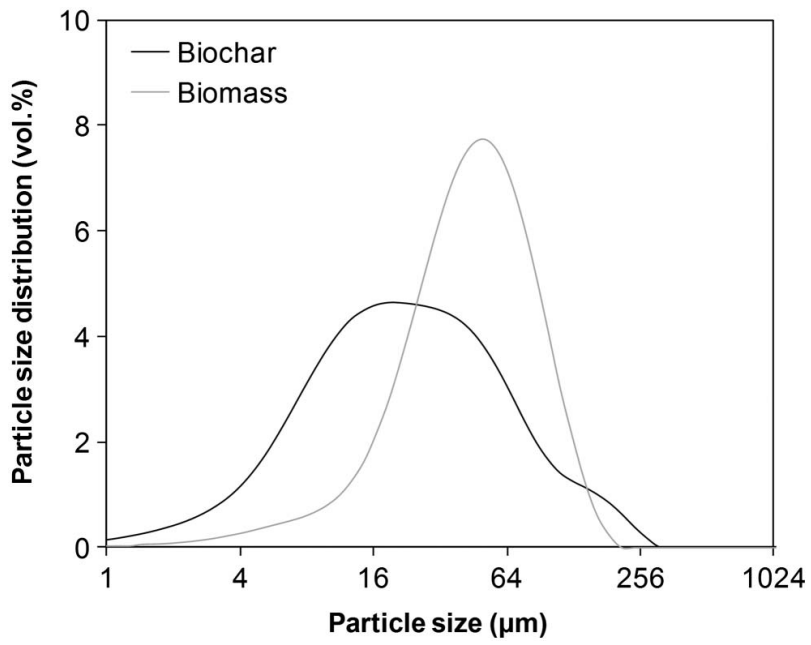

Fig. 1. Particle size distribution of the biomass and biochar.

Instruments, Malvern, United Kingdom). The results of the laser granulometry analyses are presented in Fig. 1. They show an average particle size of $60 \mu \mathrm{m}$ for the biomass and a smaller average particle size of $20 \mu \mathrm{m}$ for the biochar.

\section{Processing of the Clay Ceramic}

The clay ceramic that was investigated in this study was produced from different mixtures of clay with organic additives and water. The mixtures were prepared in a kneading bowl by mixing clay with 5,10 , or $15 \mathrm{wt} \%$ of organic additives (biomass or biochar). The mixtures were kneaded for 5 min, with a gradual addition of water up to $28 \mathrm{wt} \%$. The mixtures were then extruded with a bench extruder (Reber, Correggioverde di Dosolo, Italy) composed of a pipe and a crank-activated piston. The mixtures were pushed into the pipe and released across a die as clay blocks with dimensions of $60 \times 30 \times 10 \mathrm{~mm}^{3}$.

The clay blocks were subsequently dried at 25,65 , and $105^{\circ} \mathrm{C}$ for $24 \mathrm{~h}$ at each temperature in an electrical oven (Memmert, Schwabach, Germany). The samples were prepared from these blocks using P80, P120, P180, and P280 SiC (silicon carbide) papers (CarbiMet, Buehler, Uzwil, Switzerland). They were also fired in an air atmosphere in an electrical furnace (Controller P320, Nabertherm, Lilienthal, Germany) to produce the clay ceramic samples. The clay ceramic samples that were used for X-ray diffraction and $\mathrm{X}$-ray pair distribution function analyses were fired at 30,500 , and $1,000^{\circ} \mathrm{C}$. The rest of the clay ceramic samples were fired under the same conditions at $950^{\circ} \mathrm{C}$.

\section{Characterization of the Structure}

The atomic structure of the clay ceramic was investigated using $\mathrm{X}$-ray diffraction (XRD) analysis. Each sample in powder form was loaded into a 1-mm-diameter polyimide capillary, which was sealed at both ends with modeling clay. The capillaries were aligned on the capillary stage of the diffractometer (D8 Advance, Bruker, Madison, Wisconsin) and tested while spinning. Data were collected over a $2 \theta$ range of $2-130^{\circ}$, with a step size of $0.05^{\circ}$ and a count time per step of $30 \mathrm{~s}$, using a silver $(\mathrm{Ag})$ radiation source $(\lambda=0.56 \AA)$. The crystalline phases were identified using the Bruker EVA Suite software by matching ICDD (International Centre for Diffraction Data) database files to the Bragg peaks 


$$
G(r)=\frac{2}{\pi} \int_{Q_{\min }}^{Q_{\max }} Q[S(Q)-1] \sin (Q r) d Q
$$

Data were then used to produce the X-ray pair distribution functions (PDFs) of the clay ceramic. The background was removed using the scattering from an empty capillary. The sine Fourier transform [Eq. (1)] was applied to the total scattering functions $S(Q)$ using the PDFgetX2 software (Qiu et al. 2004). The pair distribution functions of the clay ceramic were all obtained using a maximum momentum transfer $Q_{\max }$ of $15 \AA^{-1}$.

The weight loss of the clay ceramic was measured as a function of the temperature via thermogravimetric analysis (TGA). The unfired samples were analyzed using 200-mg cylinders in a Q600 apparatus (TA Instruments, New Castle, Delaware). The data were collected in an air atmosphere at temperatures from 30 to $1,000^{\circ} \mathrm{C}$. The temperature was increased using a heating rate of $5^{\circ} \mathrm{C} / \mathrm{min}$. The percentage of organic additives was then estimated by subtracting out the weight loss of the clay ceramic without organic additives.

The deformation of the clay ceramic was measured as a function of the temperature via thermomechanical analysis (TMA). The unfired samples were analyzed using 200-mg cylinders in a Setsys 16/18 instrument (Setaram, Caluire, France). The data were collected in an air atmosphere at temperatures from 30 to $1,000^{\circ} \mathrm{C}$. The temperature was increased using a heating rate of $5^{\circ} \mathrm{C} / \mathrm{min}$. The TGA and TMA analyses were performed under the same conditions to provide accurate estimates of the bulk density (Baillez and Nzihou 2004). The bulk density $\left[\rho_{(T)}\right]$ was estimated from Eq. (2), using the measured weight loss, shrinkage, initial mass $\left(m_{0}\right)$, initial length $\left(l_{0}\right)$, and initial radius $\left(r_{\mathrm{o}}\right)$ of the samples. This gives the following:

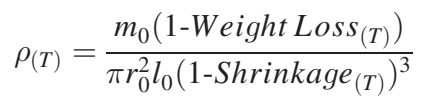

The porosity of the clay ceramic $\left[\varepsilon_{(T)}\right]$ was determined as a function of the temperature using Eq. (3), where $\rho_{(T)}$ is the bulk density and $\rho_{\text {True }}$ is the true density. The true density was measured via helium pycnometry analysis (Accupyc 1330, Micromeritics, Norcross, Georgia). The measurements of the true density (i.e., without porosity) were carried out after firing at the maximum temperature of $1,000^{\circ} \mathrm{C}$ and grinding of the samples to eliminate the porosity. The value was equivalent to $2.56 \mathrm{~g} / \mathrm{cm}^{3}$ for both the clay ceramic and the clay ceramic with organic additives since no residual organic additives remained after the previous operation. Therefore, the true density of the clay ceramic with organic additives at temperatures under $600^{\circ} \mathrm{C}$ was obtained using the measured value of the true density of the clay ceramic along with the measured value of the true density of the organic additives and the estimates of the percentage of organic additives

$$
\varepsilon_{(T)}=1-\frac{\rho_{(T)}}{\rho_{\text {True }}}
$$

The morphology of the newly formed pores in the clay ceramic was observed by scanning electron microscopy (SEM) using a Philips XL30 apparatus (Amsterdam, Netherlands). The samples were embedded in a solidifying epoxy resin and polished before imaging. The imaging was performed under back-scattered imaging (BSI) conditions, using an acceleration voltage of $20 \mathrm{kV}$ and a vacuum of 0.3 Torr, at a working distance of approximately $8.5 \mathrm{~mm}$.

\section{Capture of Cadmium}

The capture experiments were conducted using cadmium as a model for heavy metals with high volatility. Typically, they were performed in a horizontal reactor. It consisted of an alumina tube (length: $1 \mathrm{~m}$; diameter: $20 \mathrm{~mm}$ ) that was integrated in an electrical furnace (Aubry-Reverdy, Chassant, France). The accumulator was mounted on a sample holder (length: $25 \mathrm{~mm}$; diameter: $10 \mathrm{~mm}$ ) at one end of the tube. The reactor was then heated to a temperature of $650^{\circ} \mathrm{C}$, which was above the melting point of the cadmium source $\left(\mathrm{CdCl}_{2}\right.$ : cadmium chloride) at $568^{\circ} \mathrm{C}$ (Lide 2009). After reaching this temperature, a crucible with $100 \mathrm{mg}$ of $\mathrm{CdCl}_{2}$ was introduced into the tube from its other end. The tube was maintained at $650^{\circ} \mathrm{C}$ for $2 \mathrm{~h}$, with an air flow of $1 \mathrm{~L} / \mathrm{min}$ to transport the vapor toward the accumulator. Following the experiment, the accumulator was immersed in a beaker with $100 \mathrm{~mL}$ of distilled water. The beaker was then placed in an ultrasonic bath to promote the dissolution of the cadmium that was captured by the accumulator in water.

The cadmium capture efficiency of the clay ceramic was measured using inductively coupled plasma atomic emission spectroscopy (ICP-AES) analysis. The solution collected from the clay ceramic was analyzed using an Ultima 2 apparatus (Horiba, Kyoto, Japan). The cadmium concentrations obtained from ICP analyses were multiplied by the volume of the solution to determine the weight of cadmium captured in the clay ceramic. Finally, the efficiency of the clay ceramic was calculated as the ratio of the weight of cadmium captured by the clay ceramic to that of cadmium introduced into the reactor.

The mechanism of cadmium capture at high temperature was elucidated by SEM. The imaging of the cadmium particles was performed on a cross section of the clay ceramic accumulator under BSI conditions. The micrographs were obtained using an acceleration voltage of $8 \mathrm{kV}$ and a vacuum of 0.2 Torr, at a working distance of $8.5 \mathrm{~mm}$. The chemical form of the cadmium particles was also determined using energy-dispersive spectroscopy (EDS) analysis.

\section{Determination of the Mechanical Properties}

The mechanical properties of the clay ceramic were measured via three-point bending. The measurements were performed using an Instron 8548 microtester (Instron, Norwood, Massachusetts) with a 50-mm load span and a 500-N load cell. The specimens of $60 \times 10 \times 5 \mathrm{~mm}^{3}$ were loaded at a constant displacement rate of $1 \mathrm{~mm} / \mathrm{min}$ until the onset of the fracture. The mechanical strength was estimated from Eq. (4):

$$
\sigma_{f}=\frac{3 F_{\mathrm{Max}} L}{2 B H^{2}}
$$

where $\sigma_{f}=$ the mechanical strength under a flexural loading; $F_{\text {Max }}=$ the maximum force, $L=$ the loading span, $B=$ the breadth; and $H=$ the height of the specimen (ASTM 2010).

\section{Results and Discussion}

\section{Minerals}

The X-ray diffraction (XRD) patterns obtained after exposure of the clay ceramic with a $15-\mathrm{wt} \%$ addition of biochar to various temperatures $\left(30,500\right.$, and $\left.1,000^{\circ} \mathrm{C}\right)$ are shown in Fig. 2 . After exposure to a temperature of $30^{\circ} \mathrm{C}$, the clay ceramic is seen to be composed of clay minerals. The clay minerals are illite $\left[\mathrm{KAl}_{3} \mathrm{Si}_{3} \mathrm{O}_{10}(\mathrm{OH})_{2}\right]$, with a diffraction peak at $3.2^{\circ}$, and kaolinite $\left[\mathrm{Al}_{2} \mathrm{Si}_{2} \mathrm{O}_{5}(\mathrm{OH})_{4}\right]$, with a diffraction peak at $4.4^{\circ}$. The unfired clay ceramic also contains calcium carbonate, with the peak at $10.6^{\circ}$, indicating the presence of calcite $\left(\mathrm{CaCO}_{3}\right)$. Mica, quartz, and feldspar are also present in the unfired clay ceramic, as can be seen by the peaks at 7.2, 7.6, and 


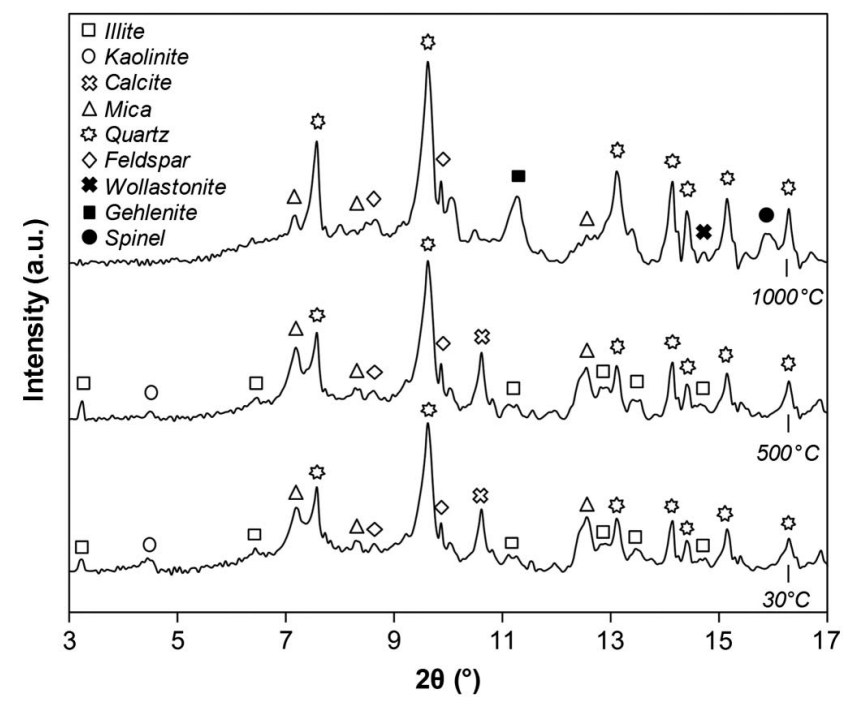

Fig. 2. X-ray diffraction patterns of the clay ceramic with a 15 -wt $\%$ addition of biochar after exposure to 30,500 , and $1,000^{\circ} \mathrm{C}$ in an air atmosphere.

$8.6^{\circ}$, respectively. No diffraction peaks indicative of the biochar are observed in the XRD pattern of the clay ceramic since biochar is an amorphous material.

The XRD pattern obtained after exposure of the clay ceramic to $500^{\circ} \mathrm{C}$ shows that the clay minerals have been modified to a certain degree. The diffraction peaks of kaolinite (e.g., at $4.4^{\circ}$ ) are eliminated in the XRD pattern of the clay ceramic due to dehydroxylation (Aras 2004). In fact, the removal of hydroxyl groups induces a development of strained and buckled layers with a transition from VI-coordinated aluminum atoms in kaolinite to V-, IV-, and III-coordinated aluminum atoms in metakaolin $\left(\mathrm{Al}_{2} \mathrm{Si}_{2} \mathrm{O}_{7}\right)$ (White et al. 2010). In contrast to kaolinite, illite conserves its diffraction peaks (e.g., at $3.2^{\circ}$ ) after exposure to $500^{\circ} \mathrm{C}$. The diffraction peaks of illite are conserved by relocation of oxygen atoms between the tetrahedral and octahedral sheets (Gualtieri and Ferrari 2006). This involves a transition from VI-coordinated aluminum atoms in illite to IV-coordinated aluminum atoms in anhydrous illite $\left(\mathrm{KAl}_{3} \mathrm{Si}_{3} \mathrm{O}_{11}\right)$ (Fernandez et al. 2011).

After exposure to $1,000^{\circ} \mathrm{C}$, the temperature-sensitive minerals are transformed into stable ceramic phases. The XRD patterns show that anhydrous illite and calcite, with diffraction peaks at 3.2 and $10.6^{\circ}$, combine into gehlenite $\left(\mathrm{Ca}_{2} \mathrm{Al}_{2} \mathrm{SiO}_{7}\right)$, with the formation of a diffraction peak at $11.2^{\circ}$ (Peters and Iberg 1978). At the depletion of anhydrous illite, calcite also combines with some amorphous silica to form wollastonite $\left(\mathrm{CaSiO}_{3}\right)(\mathrm{Cultrone}$ et al. 2001). The diffraction peaks of wollastonite (e.g., at $14.7^{\circ}$ ) are visible in the XRD pattern obtained after exposure to $1,000^{\circ} \mathrm{C}$. The XRD pattern also shows the recrystallization of metakaolin into an $\mathrm{Al} / \mathrm{Si}$ spinel phase $\left(\mathrm{Al}_{4} \mathrm{Si}_{3} \mathrm{O}_{12}\right)$ with the formation of a diffraction peak at $15.9^{\circ}$ (Sonuparlak et al. 1987). Finally, the diffraction peaks of mica, quartz, and feldspar remain at 7.2, 7.6, and 8.6 , respectively, due to the thermal stability of these minerals.

\section{Interatomic Distances}

The pair distribution functions (PDFs) obtained after exposure of the clay ceramic with a $15-\mathrm{wt} \%$ addition of biochar to different temperatures $\left(30,500\right.$, and $\left.1,000^{\circ} \mathrm{C}\right)$ are shown in Fig. 3. The atom-atom correlations confirm that the clay ceramic is composed

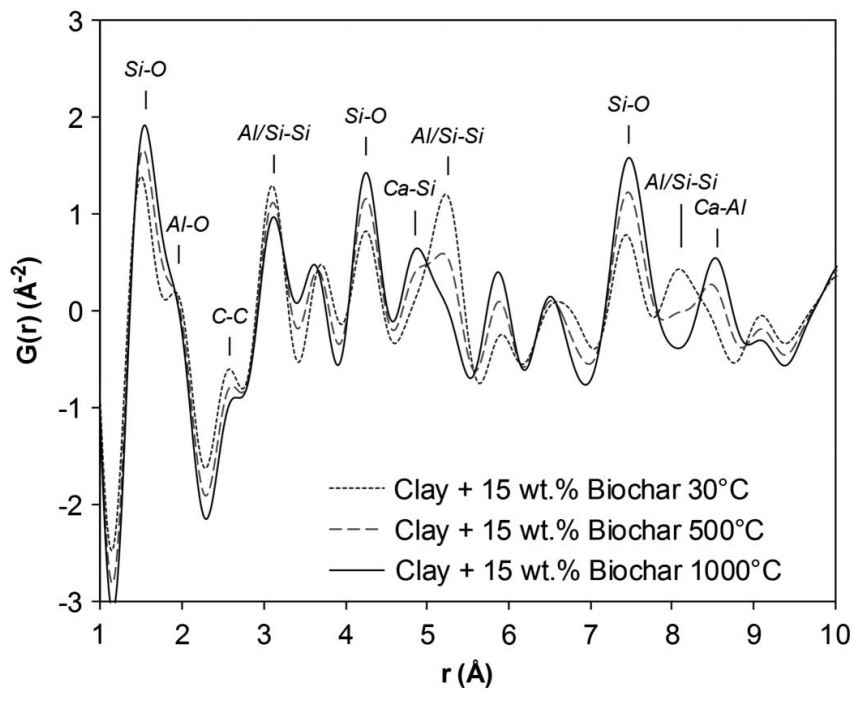

Fig. 3. X-ray pair distribution function curves of the clay ceramic with a $15-w t \%$ addition of biochar after exposure to 30,500 , and $1,000^{\circ} \mathrm{C}$ in an air atmosphere.

mainly of clay minerals after exposure to the temperature of $30^{\circ} \mathrm{C}$. The tetrahedral sheets of kaolinite and illite are represented by the Si-O correlation at $1.50 \AA$, along with the larger atom-atom distances at 4.25 and $7.44 \AA$ (Morandeau and White 2015). Moreover, the Al-O bonds of the octahedral sheets are represented by the peaks at $1.91,3.71$, and $9.11 \AA$. The distances between the silicon and aluminum atoms $(\mathrm{Si}-\mathrm{Al})$ of kaolinite and illite are also visible in the PDF curve of the clay ceramic at 3.11, 5.23, and $8.10 \AA$ A. Finally, the presence of biochar is confirmed by the C-C correlation of the aromatic cycles at $2.57 \AA$ (Petkov et al. 2013). The main C-C correlation of the aromatic cycles (i.e., at $1.43 \AA$ ) contributes to the Si-O correlation at $1.50 \AA$.

The PDF curve obtained after exposure to $500^{\circ} \mathrm{C}$ shows some changes in the intensity of the atom-atom correlations. In fact, the intensities of the peaks at 1.91, 3.71, and $9.11 \AA$ decrease as a result of the transition from VI-coordinated aluminum atoms in kaolinite and illite to mainly IV-coordinated aluminum in metakaolin and anhydrous illite. This formation of tetrahedrally coordinated aluminum sites also results in an increase in the intensity of the original Si-O correlations at $1.50,4.25$, and $7.44 \AA$. Concurrent to the changes in the intensity of the $\mathrm{Al}-\mathrm{O}$ and $\mathrm{Si}-\mathrm{O}$ correlations, the intensity of the C-C correlation at $2.57 \AA$ decreases due to thermal degradation of the biochar (Jindo et al. 2014). Carbon-containing atom-atom distances do not increase or decrease by exposure of the clay ceramic to $500^{\circ} \mathrm{C}$. This means that no interaction occurs between the clay minerals and the biochar. In fact, the biochar is eliminated on the macroscopic scale of the clay ceramic by $500^{\circ} \mathrm{C}$ with no modification in the atomic rearrangements of the clay minerals.

After exposure to $1,000^{\circ} \mathrm{C}$, the atom-atom distances attributed to the clay minerals have disappeared and new correlations indicative of the ceramic phases are present. The transformation of the $\mathrm{Al}-\mathrm{Si}$ correlation at $8.10 \AA$ into a Ca-Al correlation at $8.54 \AA$ corresponds to the combination of aluminum atoms from the initial octahedral sheets of illite with calcium atoms from calcite to form gehlenite. The PDF curve also shows the combination between the silicon atoms from the initial tetrahedral sheets of illite and the remaining calcium atoms into wollastonite with a transformation of the Al-Si correlation at $5.23 \AA$ into a $\mathrm{Ca}-\mathrm{Si}$ correlation at $4.88 \AA$. The formation of gehlenite and wollastonite after exposure of the clay 


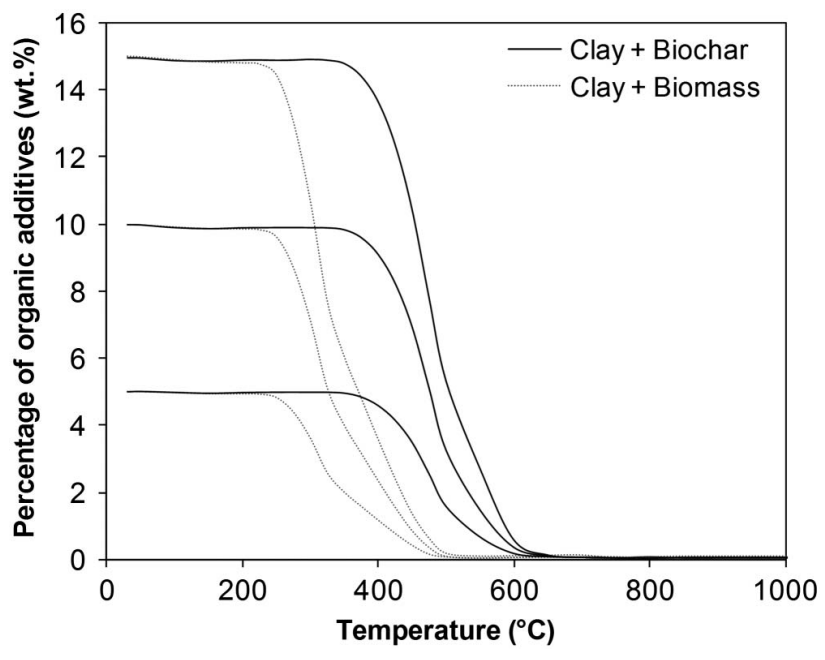

Fig. 4. Dependence of the percentage of organic additives on the firing temperature of the clay ceramic with a 5-, 10-, and 15-wt\% addition of biomass and biochar in an air atmosphere.

ceramic to $1,000^{\circ} \mathrm{C}$ occurs via limited rearrangement of the silicon and aluminum atoms due to similar atom-atom distances between the clay minerals and calcium alumino-silicates. Furthermore, it does not appear that this transformation is affected by the thermal degradation of the biochar since no carbon-containing correlations emerge during firing.

\section{Percentage of Organic Additives}

The dependence of the percentage of organic additives on the firing temperature of the clay ceramic is presented in Fig. 4. The results show that the organic additives are subjected to thermal degradation in the clay ceramic via combustion of their organic fraction in the air atmosphere (Yi et al. 2013). This transformation of the organic fraction into $\mathrm{H}_{2} \mathrm{O}$ and $\mathrm{CO}_{2}$ results in the full elimination of the organic additives due to the pure organic nature of the biomass and biochar.

The biomass is subjected to combustion in the clay ceramic at temperatures between 250 and $450^{\circ} \mathrm{C}$. Hence, the clay ceramic with a biomass addition does not contain any residual biomass after firing at $950^{\circ} \mathrm{C}$. The combustion of the biochar occurs at higher temperatures between 500 and $600^{\circ} \mathrm{C}$, since the biochar is produced by the pyrolysis of the biomass at $500^{\circ} \mathrm{C}$. Nevertheless, the clay ceramic with a biochar addition does not contain any residual biochar after firing at $950^{\circ} \mathrm{C}$.

\section{Percentage of Porosity}

The dependence of the percentage of porosity on the firing temperature of the clay ceramic is shown in Fig. 5. The clay ceramic without organic additives has a porosity of $23 \mathrm{vol} \%$ prior to the firing process (i.e., at $30^{\circ} \mathrm{C}$ ). This is from the air remaining in the mixture becoming trapped in the clay ceramic during the extrusion process. The evaporation of the mixing water during the drying process also contributes to the 23 -vol\% of porosity seen in Fig. 5 .

The dehydration of the clay ceramic induces a 2-vol\% increase in porosity at temperatures between 30 and $200^{\circ} \mathrm{C}$. The porosity is also affected by the dehydroxylation of the clay minerals between 450 and $600^{\circ} \mathrm{C}$, which lead to an additional increase of $2 \mathrm{vol} \%$. The decomposition of the calcium carbonate results in a $3-\mathrm{vol} \%$

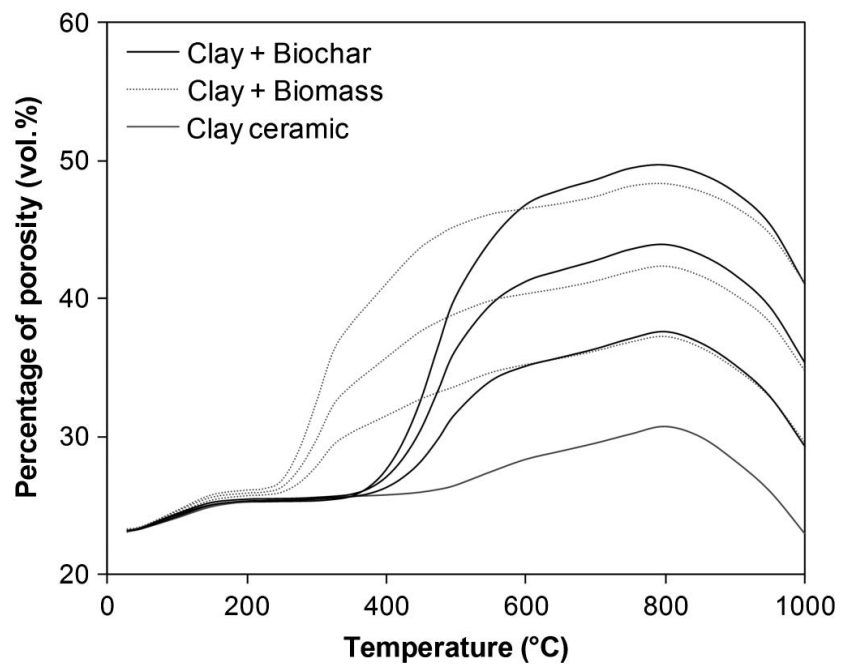

Fig. 5. Dependence of the percentage of porosity on the firing temperature of the clay ceramic and of the clay ceramic with a 5-, 10-, and $15-\mathrm{wt} \%$ addition of biomass and biochar in an air atmosphere.

increase in porosity from 650 to $850^{\circ} \mathrm{C}$. However, the porosity decreases by 4 vol\% during the sintering stage at temperatures between 850 and $950^{\circ} \mathrm{C}$. Hence, the clay ceramic has a porosity of $26 \mathrm{vol} \%$ after the firing process at $950^{\circ} \mathrm{C}$.

The addition of organic additives such as biomass and biochar results in an increase of the total amount of porosity during the firing process in comparison to the neat clay ceramic. The additional porosity formation occurs at temperatures between $250^{\circ} \mathrm{C}$ and $600^{\circ} \mathrm{C}$ and is associated with the thermal degradation of the organic additives. This porosity formed by the combustion of the biomass or biochar is conserved during the sintering stage of the clay ceramic at temperatures up to $950^{\circ} \mathrm{C}$.

The combustion of the biomass induces a $19-\mathrm{vol} \%$ formation of porosity for the case of a $15-\mathrm{wt} \%$ addition of biomass. Therefore, the clay ceramic with a $15-w t \%$ addition of biomass has a porosity of $45 \mathrm{vol} \%$ after firing at $950^{\circ} \mathrm{C}$. The biochar, which has a lower density than the biomass, results in a larger formation of porosity (20 vol\%) for a similar addition of $15 \mathrm{wt} \%$. Hence, the clay ceramic with a $15-w t \%$ addition of biochar has a slightly higher porosity of 46 vol\% after the firing process at $950^{\circ} \mathrm{C}$.

\section{Morphology of Pores}

The SEM micrographs obtained after firing of the clay ceramic at $950^{\circ} \mathrm{C}$ are presented in Fig. 6. The clay ceramic without organic additives has a clay morphology with spherical pores of $10 \mu \mathrm{m}$. These pores correspond to air that is trapped in the clay ceramic during the extrusion process. This results in the presence of isolated pores in the material with low interconnectivity. It is important to note that the clay ceramic without organic additives also contains decohesions around the $50-\mu \mathrm{m}$ particles of quartz. These are attributed to the large shrinkage of quartz compared with that of the clay particles during the $\beta \rightarrow \alpha$ quartz inversion on cooling (Tarvornpanich et al. 2008).

The clay ceramic with organic additives contains the same $10-\mu \mathrm{m}$ pores that are found in the neat clay ceramic. The newly formed pores associated with the combustion of the organic additives are also visible in the SEM micrographs, where it is seen that these pores have a morphology equivalent to that of the organic additives particles. The clay ceramic with a 15 -wt $\%$ addition of 


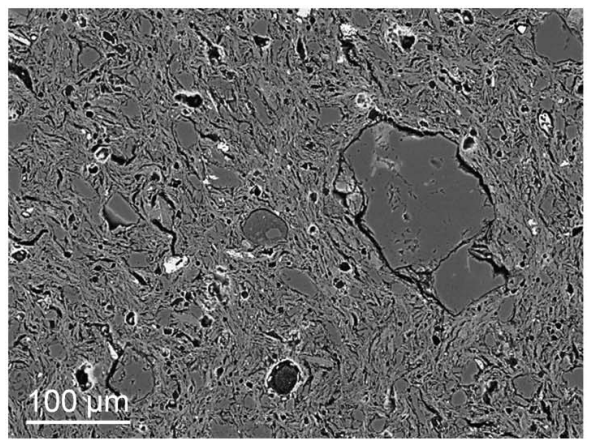

(a)

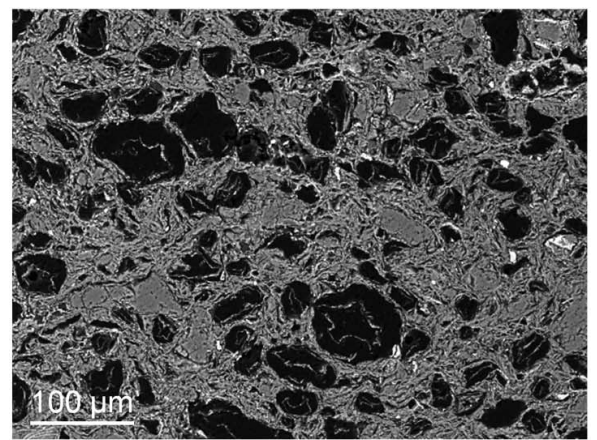

(b)

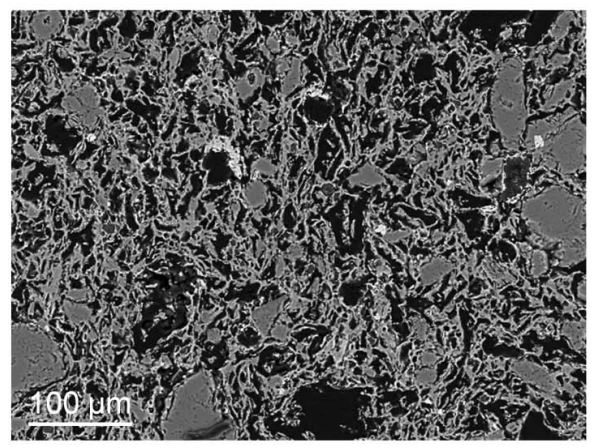

(c)

Fig. 6. SEM micrographs of (a) the clay ceramic and the clay ceramic with a 15-wt\% addition of (b) biomass and (c) biochar after firing at $950^{\circ} \mathrm{C}$ in an air atmosphere.

biomass has isolated pores with diameters of $60 \mu \mathrm{m}$. On the other hand, the clay ceramic with a $15-w t \%$ addition of biochar has $20-\mu \mathrm{m}$ pores with a higher degree of interconnectivity. It is important to note that these newly formed pores of $20 \mu \mathrm{m}$ are minor defects in the clay ceramic compared with the decohesions around the quartz particles.

\section{Efficiency of Cadmium Capture}

The dependence of the cadmium capture efficiency of the clay ceramic on the amount of organic additives is presented in Fig. 7. The clay ceramic without organic additives has a cadmium capture efficiency of $27 \%$ after firing at $950^{\circ} \mathrm{C}$. This value is associated with the percentage of porosity (i.e., $26 \mathrm{vol} \%$ ).

As mentioned previously, the addition of organic additives, such as biomass and biochar, increases the percentage of porosity. Hence, the cadmium capture efficiency of the clay ceramic increases with the percentage of organic additives because of the

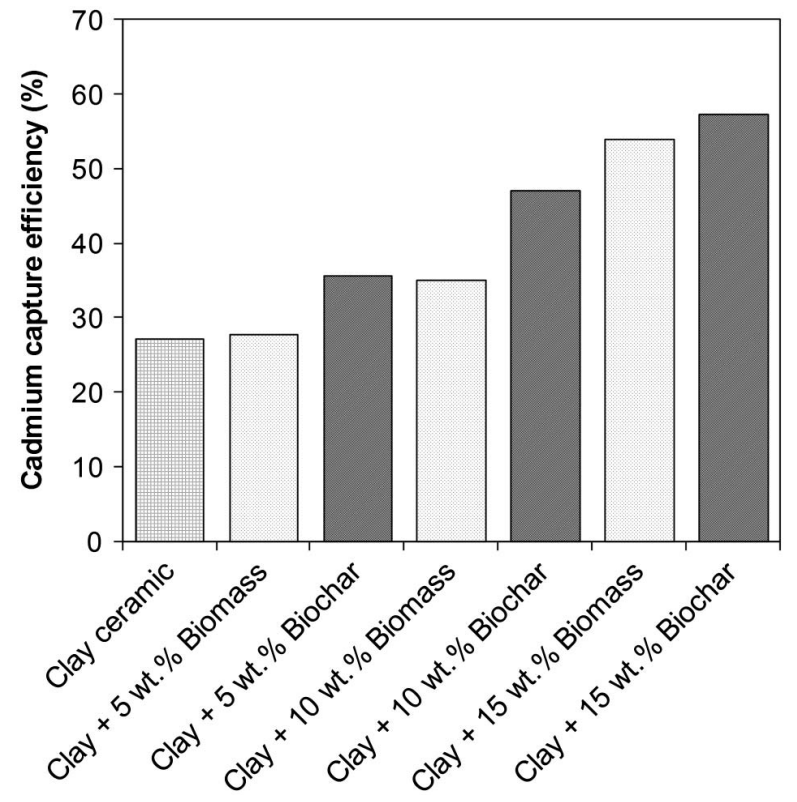

Fig. 7. Dependence of the cadmium capture efficiency of the clay ceramic on the percentage of organic additives.

porosity increase. For a same level of porosity, the clay ceramics with a biochar addition have yet a greater efficiency than the clay ceramics with a biomass addition. This is attributed to the differences in the size of the pores resulting from the combustion of the biomass or biochar. In fact, the addition of biochar with small particles results in the formation of small pores that tend to be interconnected.

The $19-\mathrm{vol} \%$ increase of the porosity results in a $27 \%$ increase of the cadmium capture efficiency using a 15 -wt $\%$ addition of biomass. Hence, the clay ceramic with a $15-\mathrm{wt} \%$ addition of biomass has a cadmium capture efficiency of 54\%. On the other hand, the $20-\mathrm{vol} \%$ increase of the porosity that results from the 15 -wt $\%$ addition of biochar increases the capture efficiency by $30 \%$. This means that the capture efficiency of the clay ceramic with a $15-w t \%$ addition of biochar reaches $57 \%$. A greater addition of biochar would result in a greater formation of interconnected pores and in a greater efficiency of the accumulators in the capture of cadmium. However, the greater volume of pores would also lead to an excessive loss in the mechanical strength.

\section{Mechanism of Cadmium Capture}

The SEM micrographs obtained after the cadmium capture experiment at $650^{\circ} \mathrm{C}$ in the clay ceramic with a $15-\mathrm{wt} \%$ addition of biomass are presented in Fig. 8. The pores resulting from the biomass combustion contain white particles of cadmium in the form of beads. The morphology of these particles indicates a capture mechanism of condensation (Buckle and Pointon 1975). In fact, the cadmium vapor condenses at this temperature $\left(650^{\circ} \mathrm{C}\right)$ because of the confining pressure in the pores (Grosman and Ortega 2008). This means that cadmium is captured by the clay ceramic at a higher temperature than the condensation temperature of cadmium $\left(568^{\circ} \mathrm{C}\right)$ in the atmosphere (Jiao et al. 2011).

The condensation of the cadmium vapor results in the formation of $2-\mu \mathrm{m}$ beads. Hence, the cadmium vapor condenses equally in the pores resulting from the combustion of biomass or biochar since both types of pores have dimensions larger than that of 


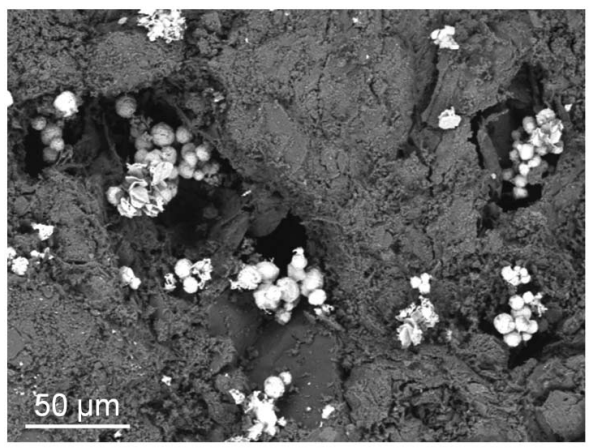

(a)

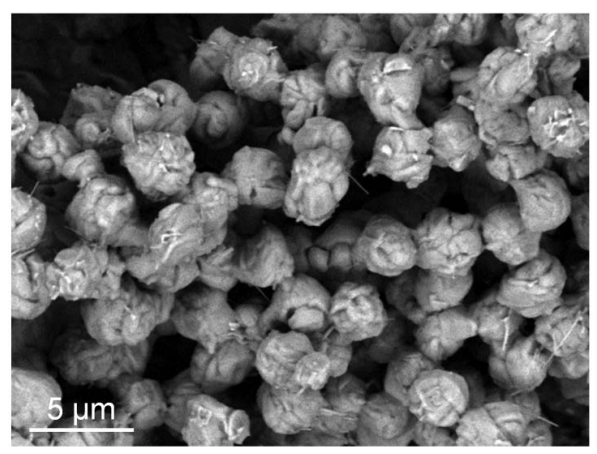

(b)

Fig. 8. SEM micrographs of (a) the clay ceramic with a 15 -wt $\%$ addition of biomass after the cadmium capture experiment; and (b) the cadmium beads in the newly formed pores of the clay ceramic with a 15 -wt $\%$ addition of biomass.

the cadmium beads. This means that the difference between the cadmium capture efficiency of the clay ceramic with large pores, resulting from the combustion of the biomass, and that of the clay ceramic with small pores, resulting from the combustion of the biochar, is not from differences in the mechanism of cadmium capture. Instead, the difference observed earlier arises from the fact that the small pores tend to be interconnected, which gives the cadmium vapor access to a greater volume of porosity in which it can condense. These results indicate that the cadmium capture efficiency of the clay ceramic accumulator depends on the percentage of porosity and the interconnectivity of the pores (permeability).

\section{Chemical Form of Cadmium}

The X-ray spectroscopy patterns of the surrounding and central area of a cadmium-loaded pore are presented in Fig. 9. The surrounding area is composed of silicon, aluminum, and oxygen with smaller concentrations of calcium, potassium, and magnesium. Therefore, it consists of fired clay. No cadmium adsorption on the clay can be observed from the X-ray spectroscopy pattern of the surrounding area. This means that the composition of the clay ceramic accumulator has no effect on the cadmium capture. In fact, all of the cadmium is captured by condensation in the pores. The central area of the cadmium-loaded pore is composed of the same elements that make up the surrounding area, due to the proximity of clay, together with cadmium and chlorine. The intensity of the cadmium peak is two times smaller than that of chlorine. This means that cadmium is captured by the clay ceramic accumulator at high temperatures in the form of cadmium chloride $\left(\mathrm{CdCl}_{2}\right)$, which is the same form as the cadmium source.

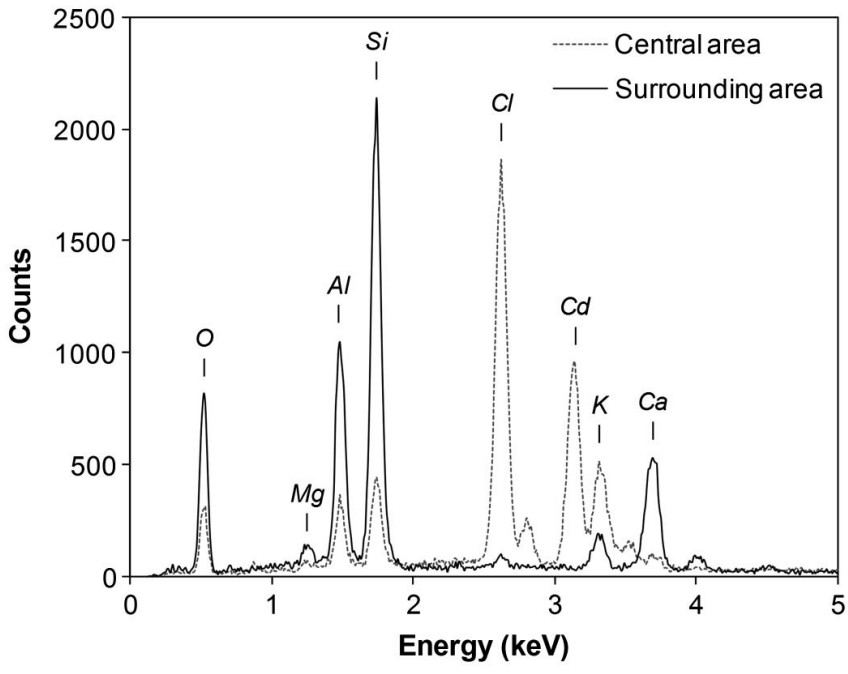

Fig. 9. X-ray spectroscopy patterns of the surrounding area and of the central area of a cadmium-loaded pore of the clay ceramic with a $15-\mathrm{wt} \%$ addition of biomass.

\section{Mechanical Strength}

The dependence of the mechanical strength of the clay ceramic on the percentage of organic additives is shown in Fig. 10. The clay ceramic without organic additives has an average mechanical strength of $21.6 \mathrm{MPa}$ after firing at $950^{\circ} \mathrm{C}$. This value represents a combination between the bonding of the clay particles and the presence of major defects, such as the $50-\mu \mathrm{m}$ decohesions around the quartz particles.

The addition of organic additives in the clay ceramic induces a decrease in the mechanical strength. However, the extent of the decrease depends on the particle sizes of the organic additives. The organic additives with large particles (i.e., biomass) lead to the formation of large pores compared to the decohesions around the quartz particles. Such pores act as crack nucleation sites, which results in a loss of the mechanical strength. On the other hand, the organic additives with small particles (i.e., biochar) induce a formation of pores with small dimensions compared to the other

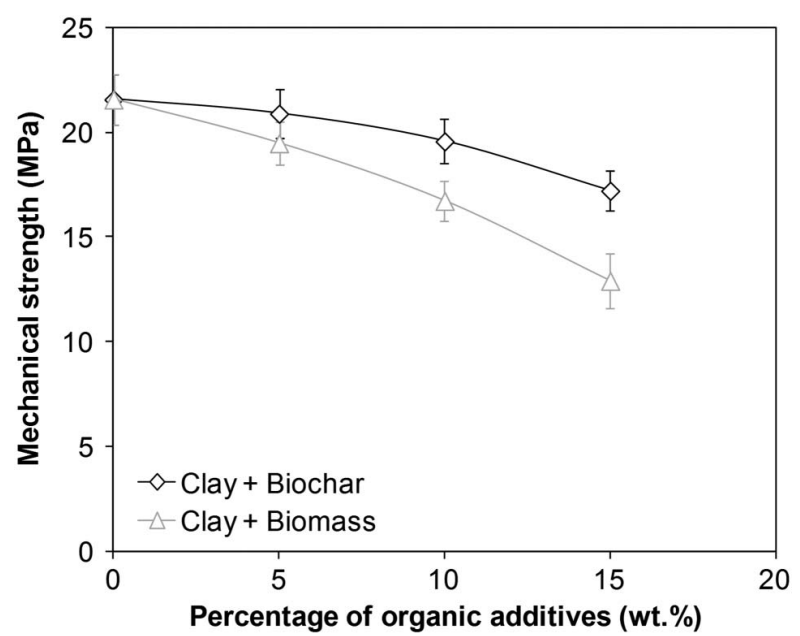

Fig. 10. Dependence of the mechanical strength of the clay ceramic on the percentage of organic additives. 
defects of the structure that results in a minor loss of the mechanical strength.

The mechanical strength of the clay ceramic decreases by $40 \%$ in the case of a 15-wt $\%$ addition of biomass that produces large pores of $60 \mu \mathrm{m}$. On the other hand, the 15 -wt $\%$ addition of biochar only causes a $20 \%$ decrease in the mechanical strength as a result of the formation of small $20-\mu \mathrm{m}$ pores. This means that the clay ceramic conserves a high mechanical strength of $17.2 \mathrm{MPa}$ for a 15 -wt $\%$ addition of biochar.

\section{Implications}

The implications of this research are relevant for the use of porous ceramics in capturing heavy metals. The capture of heavy metals by the collection of fly ash is well controlled in thermal conversion systems. Nevertheless, the contamination of fly ash limits the extent to which this material can be recycled in road and concrete applications.

This work shows that heavy metals can be captured before the contamination of fly ash via circulation of the vapor through porous ceramics inserted directly after the furnace. In fact, the heavy metals are captured by condensation of their vapor in the pores at higher temperatures than the condensation temperature of the heavy metals in the atmosphere as a result of the internal pressure. The capture efficiency of such a clay ceramic reaches up to $57 \%$ in this study, using biochar as a pore-forming agent. Moreover, the clay ceramics are seen to be particularly well suited for this application in thermal conversion systems with a mechanical strength of 17.2 $\mathrm{MPa}$.

In such a process, the capture is achieved regardless of the chemical form of the source of heavy metals, since the elements split up at the working temperature. Furthermore, the heavy metals are not subjected to any adsorption in the clay. This means that heavy metals that condense in the pores can be removed by dissolution using a fluid circulating system. In this way, the clay ceramics may be reused after the removal of the heavy metals to prevent any increase in the total amount of thermal conversion residues.

\section{Conclusions}

In this paper, a clay ceramic with organic additives (biomass and biochar) was investigated for the development of highly porous accumulators to capture heavy metals in thermal conversion systems. Salient conclusions arising from this study are summarized below:

1. The firing process induced a combination of the temperaturesensitive minerals at the atomic scale. On the other hand, the organic additives combusted on the macroscopic scale of the clay ceramic. It was found that the combination of the clay minerals and calcite into calcium alumino-silicates was not affected by the combustion of the organic additives.

2. The organic additives transformed into $\mathrm{H}_{2} \mathrm{O}$ and $\mathrm{CO}_{2}$, whose release increased the porosity of the clay ceramic. The morphology of the pores was equivalent to that of the organic additives. Furthermore, the small pores had a greater interconnectivity than the large pores.

3. Cadmium was captured by condensation of the vapor as $2-\mu \mathrm{m}$ beads in the pores. The cadmium capture efficiency of the clay ceramic accumulator was seen to vary as a function of the percentage of porosity, and the accumulator had a higher efficiency with small pores that enhanced the access of cadmium vapor to a greater volume of porosity.

4. The cadmium capture was achieved at higher temperatures than the condensation temperature of cadmium in the atmosphere. This suggests that cadmium vapor can be captured before it condenses in fly ash of thermal conversion systems. Moreover, the accumulators can be reused to prevent any increase in the total amount of thermal conversion residues.

\section{Acknowledgments}

The authors would like to acknowledge the CARNOT Mines Institute, the SOLSTICE Laboratory of excellence, and the RAPSODEE Research Center at Mines Albi for financial support. The authors are also grateful to the management and staff of the Department of Mechanical and Aerospace Engineering, the Department of Civil and Environmental Engineering, and the Andlinger Center for Energy and the Environment at Princeton University, as well as the Department of Mechanical Engineering at WPI for their assistance with the research. Mr. Kengran Yang is also thanked for performing the X-ray diffraction analyses in this study.

\section{References}

Abanades, S., G. Flamant, and D. Gauthier. 2002. "Kinetics of heavy metal vaporization from model wastes in a fluidized bed." Environ. Sci. Technol. 36 (17): 3879-3884. https://doi.org/10.1021/es020037e.

Aras, A. 2004. "The change of phase composition in kaolinite and illite-rich clay-based ceramic bodies." Appl. Clay Sci. 24 (3-4): 257-269. https:// doi.org/10.1016/j.clay.2003.08.012.

ASTM. 2010. Standard test methods for flexural properties of unreinforced and reinforced plastics and electrical insulating materials. ASTM D790. West Conshohocken, PA: ASTM.

Baillez, S., and A. Nzihou. 2004. "The kinetics of surface area reduction during isothermal sintering of hydroxyapatite adsorbent." Chem. Eng. J. 98 (1-2): 141-152. https://doi.org/10.1016/j.cej.2003.07.001.

Bridgwater, A. V. 2003. "Renewable fuels and chemicals by thermal processing of biomass." Chem. Eng. J. 91 (2-3): 87-102. https://doi .org/10.1016/S1385-8947(02)00142-0.

Bridgwater, A. V. 2012. "Review of fast pyrolysis of biomass and product upgrading." Biomass Bioenergy 38: 68-94. https://doi.org/10.1016/j .biombioe.2011.01.048.

Buckle, E. R., and K. C. Pointon. 1975. "Condensation of cadmium aerosols." J. Mater. Sci. 10 (3): 365-378. https://doi.org/10.1007 /BF00543679.

Carty, W. M., and U. Senapati. 1998. "Porcelain: Raw materials, processing, phase evolution, and mechanical behavior." J. Am. Ceram. Soc. 81 (1): 3-20. https://doi.org/10.1111/j.1151-2916.1998.tb02290.x.

Chen, J. C., M. Y. Wey, and Z. S. Liu. 2001. "Adsorption mechanism of heavy metals on sorbents during incineration." J. Environ. Eng. 127 (1): 63-69. https://doi.org/10.1061/(ASCE)0733-9372(2001)127:1(63).

Cultrone, G., C. Rodriguez-Navarro, E. Sebastian, O. Cazalla, and M. J. De La Torre. 2001. "Carbonate and silicate phase reactions during ceramic firing." Eur. J. Miner. 13 (3): 621-634. https://doi.org/10.1127/0935 -1221/2001/0013-0621.

Dong, J., Y. Chi, Y. Tang, M. Ni, A. Nzihou, E. Weiss-Hortala, and Q. Huang. 2015. "Partitioning of heavy metals in municipal solid waste pyrolysis, gasification, and incineration.” Energy Fuels 29 (11): 7516-7525. https://doi.org/10.1021/acs.energyfuels.5b01918.

Fernandez, R., F. Martirena, and K. L. Scrivener. 2011. "The origin of the pozzolanic activity of calcined clay minerals: A comparison between kaolinite, illite and montmorillonite." Cem. Concr. Res. 41 (1): 113-122. https://doi.org/10.1016/j.cemconres.2010.09.013.

Ferreira, C., A. Ribeiro, and L. Ottosen. 2003. "Possible applications for municipal solid waste fly ash." J. Hazard. Mater. 96 (2-3): 201-216. https://doi.org/10.1016/S0304-3894(02)00201-7.

Garg, A., R. Smith, D. Hill, N. Simms, and S. Pollard. 2007. "Wastes as co-fuels: The policy framework for solid recovered fuel (SRF) in Europe, with UK implications." Environ. Sci. Technol. 41 (14): 4868-4874. https://doi.org/10.1021/es062163e.

Grosman, A., and C. Ortega. 2008. "Capillary condensation in porous materials. Hysteresis and interaction mechanism without pore 
blocking/percolation process." Langmuir 24 (8): 3977-3986. https://doi .org/10.1021/la703978v.

Gualtieri, A. F., and S. Ferrari. 2006. "Kinetics of illite dehydroxylation." Phys. Chem. Miner. 33 (7): 490-501. https://doi.org/10.1007/s00269 -006-0092-Z.

Jiao, F., Y. Cheng, L. Zhang, N. Yamada, A. Sato, and Y. Ninomiya. 2011. "Effects of $\mathrm{HCl}, \mathrm{SO}_{2}$ and $\mathrm{H}_{2} \mathrm{O}$ in flue gas on the condensation behavior of $\mathrm{Pb}$ and $\mathrm{Cd}$ vapors in the cooling section of municipal solid waste incineration." Proc. Combust. Inst. 33 (2): 2787-2793. https://doi.org /10.1016/j.proci.2010.07.062.

Jindo, K., H. Mizumoto, Y. Sawada, M. A. Sanchez-Monedero, and T. Sonoki. 2014. "Physical and chemical characterization of biochars derived from different agricultural residues." Biogeosciences 11 (23): 6613-6621. https://doi.org/10.5194/bg-11-6613-2014.

Kampa, M., and E. Castanas. 2008. "Human health effects of air pollution." Environ. Pollut. 151 (2): 362-367. https://doi.org/10.1016/j.envpol .2007.06.012.

Kemiha, M., D. Pham Minh, N. Lyczko, A. Nzihou, and P. Sharrock. 2014. "Highly porous calcium hydroxyapatite-based composites for air pollution control." Procedia Eng. 83: 394-402. https://doi.org/10.1016/j .proeng.2014.09.044.

Lavric, E. D., A. A. Konnov, and J. De Ruyck. 2004. "Dioxin levels in wood combustion-A review." Biomass Bioenergy 26 (2): 115-145. https://doi.org/10.1016/S0961-9534(03)00104-1.

Levasseur, B., M. Chartier, J. F. Blais, and G. Mercier. 2006. "Metals removal from municipal waste incinerator fly ashes and reuse of treated leachates." J. Environ. Eng. 132 (5): 497-505. https://doi.org/10.1061 /(ASCE)0733-9372(2006)132:5(497).

Lide, D. R. 2009. Handbook of chemistry and physics. Boca Raton, FL: CRC Press.

Luo, Z., and J. Zhou. 2012. "Thermal conversion of biomass.” In Handbook of climate change mitigation, edited by W. Chen, J. Seiner, T. Suzuki, and M. Lackner. New York: Springer.

McKendry, P. 2002. "Energy production from biomass (Part 2): Conversion technologies." Bioresour. Technol. 83 (1): 47-54. https://doi.org/10 .1016/S0960-8524(01)00119-5.

Morandeau, A. E., and C. E. White. 2015. "In-situ X-ray pair distribution function analysis of accelerated carbonation of a synthetic calciumsilicate-hydrate gel." J. Mater. Chem. A 3 (16): 8597-8605. https://doi .org/10.1039/C5TA00348B.

Narodoslawsky, M., and I. Obernberger. 1996. "From waste to raw material-The route from biomass to wood ash for cadmium and other heavy metals." J. Hazard. Mater. 50 (2-3): 157-168. https://doi.org/10 .1016/0304-3894(96)01785-2.

Pacyna, E. G., J. M. Pacyna, J. Fudala, E. Strzelecka-Jastrzab, S. Hlawiczka, D. Panasiuk, S. Nitter, T. Pregger, H. Pfeiffer, and R. Friedrich. 2007. "Current and future emissions of selected heavy metals to the atmosphere from anthropogenic sources in Europe." Atmos. Environ. 41 (38): 8557-8566. https://doi.org/10.1016/j.atmosenv 2007.07.040.

Peters, T., and R. Iberg. 1978. "Mineralogical changes during firing of calcium-rich brick clays." Ceram. Bull. 57 (5): 503-509.

Petkov, V., Y. Ren, S. Kabekkodu, and D. Murphy. 2013. "Atomic pair distribution functions analysis of disordered low-z materials." Phys. Chem. Chem. Phys. 15 (22): 8544-8554. https://doi.org/10.1039 /c2 $\mathrm{cp} 43378 \mathrm{~h}$.

Qiu, X., J. W. Thompson, and S. J. L. Billinge. 2004. "PDFgetX2: A GUI-driven program to obtain the pair distribution function from X-ray powder diffraction data." J. Appl. Cryst. 37 (4): 678. https:// doi.org/10.1107/S0021889804011744.

Sonuparlak, B., M. Sarikaya, and I. A. Aksay. 1987. "Spinel phase formation during the $980^{\circ} \mathrm{C}$ exothermic reaction in the kaolinite-to-mullite reaction series." J. Am. Ceram. Soc. 70 (11): 837-842. https://doi .org/10.1111/j.1151-2916.1987.tb05637.x.

Steubing, B., R. Zah, and C. Ludwig. 2012. "Heat, electricity, or transportation? The optimal use of residual and waste biomass in Europe from an environmental perspective." Environ. Sci. Technol. 46 (1): 164-171. https://doi.org/10.1021/es202154k.

Tarvornpanich, T., G. P. Souza, and W. E. Lee. 2008. "Microstructural evolution in clay-based ceramics. Part II: Ternary and quaternary mixtures of clay, flux, and quartz filler." J. Am. Ceram. Soc. 91 (7): 2272-2280. https://doi.org/10.1111/j.1551-2916.2008.02394.x.

Vehlow, J. 2015. "Air pollution control systems in WtE units: An overview." Waste Manage. 37: 58-74. https://doi.org/10.1016/j.wasman .2014.05.025.

White, C. E., J. L. Provis, T. Proffen, D. P. Riley, and J. S. J. Van Deventer. 2010. "Density functional modeling of the local structure of kaolinite subjected to thermal dehydroxylation." J. Phys. Chem. A 114 (14): 4988-4996. https://doi.org/10.1021/jp911108d.

Wiedinmyer, C., R. J. Yokelson, and B. K. Gullett. 2014. "Global emissions of trace gases, particulate matter, and hazardous air pollutants from open burning of domestic waste." Environ. Sci. Technol. 48 (16): 9523-9530. https://doi.org/10.1021/es502250z.

Williams, A., J. M. Jones, L. Ma, and M. Pourkashanian. 2012. "Pollutants from the combustion of solid biomass fuels." Prog. Energy Combust. Sci. 38 (2): 113-137. https://doi.org/10.1016/j.pecs.2011.10.001.

Yang, C. L., and M. Beltran. 2000. "Electrostatic precipitator for metal and particulate emission control." J. Environ. Eng. 126 (3): 233-238. https://doi.org/10.1061/(ASCE)0733-9372(2000)126:3(233).

Yi, Q., F. Qi, G. Cheng, Y. Zhang, B. Xiao, Z. Hu, S. Liu, H. Cai, and S. Xu. 2013. "Thermogravimetric analysis of co-combustion of biomass and biochar.” J. Therm. Anal. Calorim. 112 (3): 1475-1479. https://doi .org/10.1007/s10973-012-2744-1. 